\title{
Open-Eco-Innovation for SMEs with Pan-European Key Enabling Technology Centres
}

\author{
Faruk Civelek $^{1, *\left(\mathbb{D} \text {, Romit Kulkarni }{ }^{1}{ }^{1} \text {, Karl-Peter Fritz }\right.}{ }^{1}$, Tanja Meyer ${ }^{2}$, Costas Troulos ${ }^{3}$, \\ Thomas Guenther ${ }^{1,4}$ and André Zimmermann ${ }^{1,4}$ \\ 1 Hahn-Schickard, Allmandring 9 b, 70569 Stuttgart, Germany; romit.kulkarni@hahn-schickard.de (R.K.); \\ Karl-Peter.Fritz@Hahn-Schickard.de (K.-P.F.); thomas.guenther@ifm.uni-stuttgart.de (T.G.); \\ andre.zimmermann@ifm.uni-stuttgart.de (A.Z.) \\ 2 Bio Base Europe Pilot Plant (BBEPP), Rodenhuizekaai 1, 9042 Desteldonk, Belgium; tanja.meyer@bbeu.org \\ 3 Praxi Network, Kolokotroni str. 8, GR-10561 Athens, Greece; troulos@praxinetwork.gr \\ 4 Institute for Micro Integration (IFM), University of Stuttgart, 70569 Stuttgart, Germany \\ * Correspondence: Faruk.Civelek@hahn-schickard.de; Tel.: +49-711-685-60782
}

Received: 26 August 2020; Accepted: 8 October 2020; Published: 13 October 2020

check for updates

\begin{abstract}
The project "key enabling technologies for clean production" (KET4CP), which is supported by the European Commission, has the aim to connect small and medium-sized enterprises (SME) and Technology Centres (TC) for cleaner, greener and more efficient production. Within this context, SMEs and TCs across Europe work together to establish an open-innovation network and to raise awareness in productivity and environmental performance. This article presents how an open European network of TCs opens its innovation process to support SMEs to become cleaner, greener and more efficient. Furthermore, this article shows how the TCs and SMEs become a part of the open-eco-innovation platform in clean production and how successful the open-eco-innovation process of different European countries is. We revealed that a pan-European open innovation process for eco-innovations with TCs for key enabling technologies (KET TCs) and Enterprise Europe Network partners (EEN) is a successful approach for SMEs that want to produce and develop cleaner products. An application example is mentioned, in which TCs from different European countries have contributed to developing a product of a SME for energy harvesting. The SME, together with the TCs, developed a generator that is installed in city-level water supply pipes and so, it is outstanding in its application. This innovative application is also described in this article.
\end{abstract}

Keywords: open-innovation; eco-innovation; key enabling technologies; technology centres; CFD-simulation; water turbine; energy harvesting

\section{Introduction}

There is no clear and commonly agreed definition of open-eco-innovation. Phills et al. (2008) defines that innovation is both a process and a product and it must meet two criteria. The first is that they must be new to the user, context, or application and second is that it must be either more effective or more efficient than pre-existing alternatives [1]. As it is difficult to find a comprehensive definition of innovation in the theory, one possibility is to base the definition on the classification [2]. Therefore, the result of this paper is a classification according to Figure 1 for the presented case study. This matrix distinguishes changes in form and changes in components while both are subsequently categorised into incremental and radical changes [2,3]. Extensive research is, however, available in the field of taxonomy of innovation, its application in the context of innovation process [4,5]. Open Innovation in general describes the innovation process as "a multi-layered open search and solution process" that occurs between several actors across company boundaries [6]. Chesbrough (2006) 
introduced this concept and defined it as follows: "open innovation is a paradigm that assumes that firms can and should use external ideas as well as internal ideas, and internal and external paths to market, as the firms look to advance their technology" [7]. The interdisciplinary project "Innovation Effects of Environmental Policy Instruments" introduced the concept of eco-innovation which was defined relatively generally by Klemmer et al. (1999). They defined eco-innovation as an action of all relevant actors (enterprises, politics, trade unions, associations, churches, private households) that develop, apply or introduce new ideas, practices, products and processes that contribute to reducing environmental impacts or to ecologically predetermined sustainability objectives. Eco-innovations can be developed by companies or non-profit organisations, they can be traded on markets or not, they can be technological, organisational, social or institutional [8]. Therefore, the concept of eco-innovation is defined as another term for innovation for the environment and includes environmentally beneficial innovations. Others see eco-innovation as a synonym for sustainable innovation [9]. The usage of open-innovation processes for eco-innovations could be called "open-eco-innovation". For pan-European open-eco-innovation it is still unclear which factors are relevant to stimulate the success of innovation activities of small and medium-sized enterprises (SMEs). This paper describes how a pan-European open-eco-innovation process can be managed, how successful it is and what the challenges are.

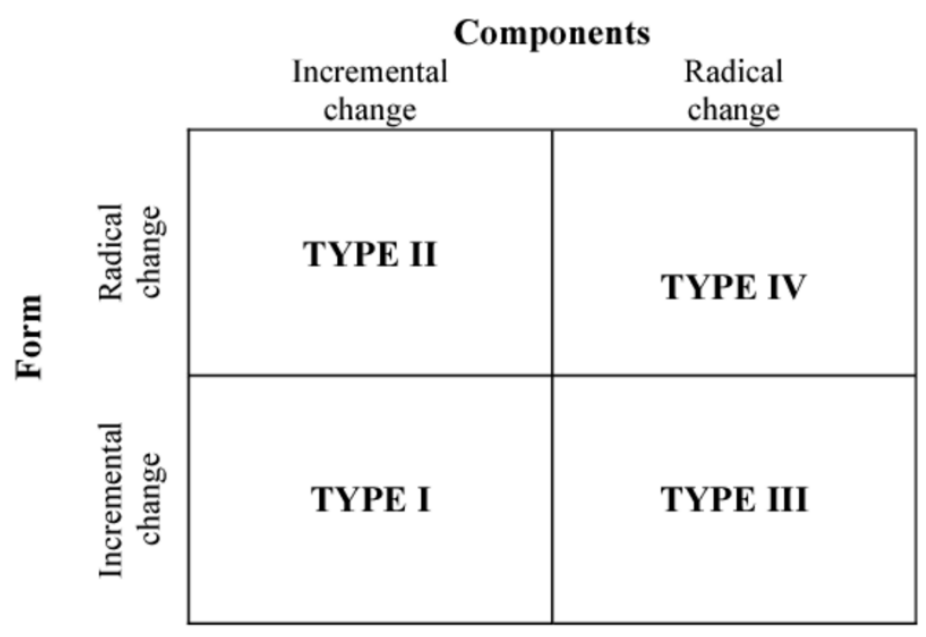

Figure 1. Matrix system of classification of product innovation, Source: Harbour and Blackman, 2006.

The main objective of the project Key Enabling Technologies for Clean Production (KET4CP) is to foster the use of advanced manufacturing technologies and related KETs by SMEs to upgrade their production processes towards resource and energy efficiency as well as sustainability, to develop environmentally friendly products and also products that affect the environment positively. To support this goal, the project aims to create an open innovation ecosystem with a one-stop-shop via an online platform for a pan-European and cross-border access to innovation services for SME through a network of superior KET TC that ensure a clean production. KET4CP will facilitate the access of manufacturing SMEs to technology services and facilities situated in other European member states and enable cross-border cooperation. The project objectives are

- reaching out manufacturing SME all over EU-28 with the support of the Enterprise Europe Network,

- raising their awareness on the potential of clean production innovation for increased product quality, productivity and environmental performance,

- facilitating SMEs connectivity to KET TC into joint project proposals for micro grants.

After a pilot phase with several SME innovation projects supported by micro grants, the plan is to scale up the network by adding more KET TCs and members of the EEN, to reach a critical mass of clean production technology deployment in SME. The final aim is to create a sustainable 
platform that is facilitating SMEs clean resource- and energy efficient production and strengthening their competitiveness. The aim is to achieve that through KET4CP by the year 2021.

There is no contextual open innovation process in the literature that specifically considers clean development and production for SMEs. The approach of an open-eco-innovation process in the project KET4CP will be presented and tested in this article. Challenges, such as formulating technical problems of SMEs, finding ideas with SMEs and TCs and the collaborative development for greener products are also presented and illustrated with an example. In this example, the SME, together with the TCs, developed a generator that is installed in city-level water supply pipes which makes a positive impact on the environment.

This paper is based on the theory building and testing design research methodology of Eisenhardt et al. (2007). There are four steps in this framework Figure 2: relevance of the research and research questions, theory building, empirical testing and theory testing [10]. The first step was shown in the introduction. The respondents of the survey originate from 12 different EU member states and contain 108 SMEs [11]. The second step involves the design of a new theory and method of open eco-innovation based on the existing state-of-the-art and experts from 12 KET TCs and seven EENs. These experts are dealing with the questions that are generated in the first step with a literature review and a survey. The Sections 2.1.1-2.1.3 show the results of the workshop. Section 2.2 contains the empirical testing with a real case study. In this, the results of the open-eco-innovation process will be shown in this paper. The fourth step is not presented in this paper. The first three steps were carried out by using different research tools like surveys, workshops with the stakeholder and experts and case studies.

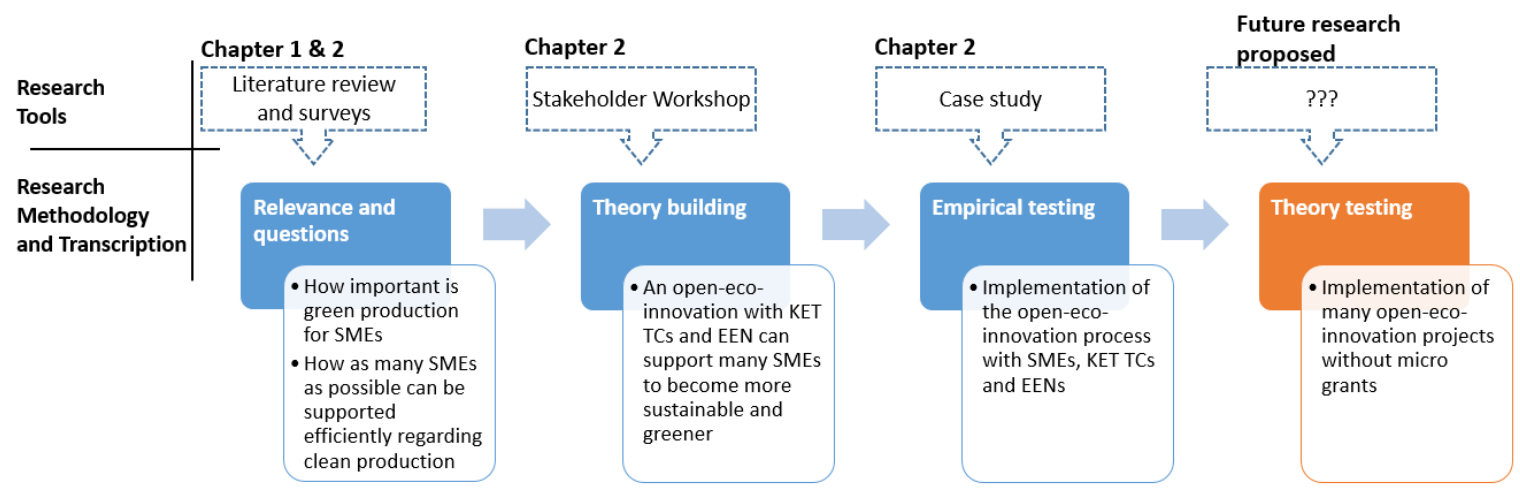

Figure 2. Design research methodology in combination with research tools.

Consequently, it can be called a mixed-method design that is recommended for application from theory to practice [12]. The main objective of this research is to define the term open-eco-innovation as well as to describe and test this process empirically, which is shown in the following chapters in more detail.

\section{Methodology}

The production of environmentally friendly products is already an added value for customers and plays an increasingly important role in companies $[13,14]$. Green production is no longer a marginal issue for most SMEs, even the ones not directly affected by environmental regulations [15]. A survey carried out as part of the project has shown that $70 \%$ of the respondents consider clean, sustainable and green production as important or very important (Figure 3), whereas $80 \%$ of the respondents consider the optimisation of production facilities as important or very important (Figure 4) [11]. More than half $(55 \%)$ of the SMEs noted that they plan to use external support to implement business and process improvements for their company [16]. These findings raise the questions: how can as many SMEs as possible be supported efficiently regarding green product and process innovation? What could an open innovations process look like in this context? 


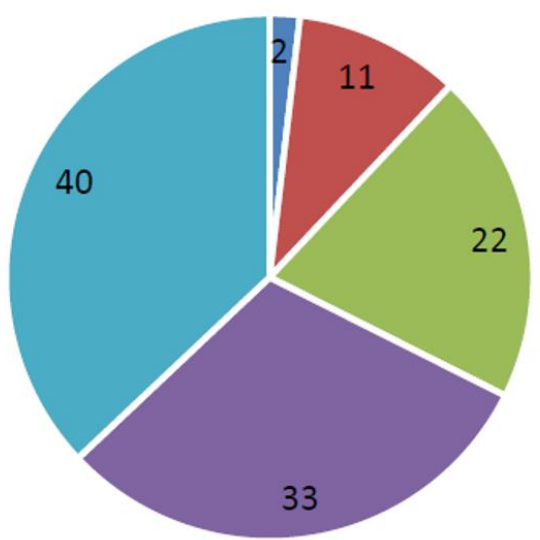

Number of respondent SMEs are 108

- Not at all important - Slightly important

- Moderately important - Important

- Very Important

Figure 3. How important is clean, sustainable or green production for your company?

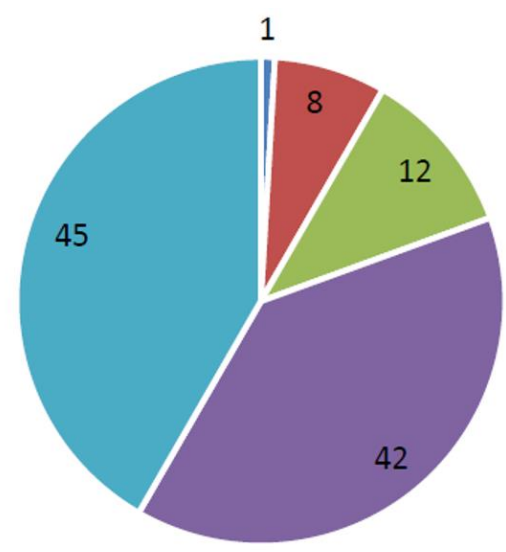

Number of respondent SMEs are 108

- Not at all important - Slightly important

- Moderately important - Important

- Very Important

Figure 4. How important is optimising production facilities for your company?

That means it will be needed in the future to explore by SMEs different fields of engineering and key enabling technologies (KETs) (e.g., nanotechnology, industrial biotechnology, photonics, advanced manufacturing, nano and microelectronics). Additionally, the implementation of environmentally friendly products often requires skills from different engineering disciplines in particular disciplines in the field of these key enabling technologies [17]. However, SMEs are characterised by very specific professional skills [18], hence particularly for SMEs it is difficult and expensive to engage in the development and production of innovative, environmentally friendly products because their capacities are often insufficient. Especially old enterprises are not prepared to produce in an environmentally friendly way or to develop environmentally friendly products [19]. Innovative clean production has the potential to increase product quality, productivity and environmental performance, and thereby, to enhance SMEs competitiveness [20]. One way to foster SMEs to make use of those interdisciplinary approaches, which they need to become "greener", is open-innovation and cooperation with technology centres (TC) and industry [21,22]. TCs for KET, so called KET TCs, can upgrade production processes 
of manufacturing SMEs towards resource and energy efficiency, a support for the development of products that will help to save the environment would be provided. It is widely recognised and acknowledged that open innovation plays an important role in finding and integrating external knowledge for successful innovation of a company [23-25]. Furthermore, open innovation is an ideal way to support eco-innovative SMEs, especially because of the need to internationalise new green technologies quickly [25]. In general, the open innovation process is risky for many SMEs. Information and communication costs, high complexity as well as the quality and trust are risks for the companies [26]. Therefore, an open innovation ecosystem with a one-stop access platform for cross-border innovation services for manufacturing SMEs through a network of superordinate KET TCs and partners of the Enterprise Europe Network (EEN) is needed. EEN partners are important because they have an independent and impartial role in this project. Furthermore, EEN partners are concentrating on organisational measures and marketing actions to bring the SMEs and KET TC in a platform. A platform like this will be achieved by facilitating the connection of SMEs to the KET TCs through joint project proposals. The project KET4CP was initiated, inter alia, for the above-mentioned reasons.

\subsection{Open-Eco-Innovation Process}

The open-eco-innovation process consists of 20 partners from 18 European countries. This composition of partners is based on the general idea of pairing two main groups of actors. The first group consists of 12 technology centres for key enabling technologies (KET TCs) with specific knowledge in the field of key technologies. The key technologies are nanotechnologies, photonics, advanced manufacturing, industrial biotechnologies, advanced materials and microelectronics. The KET TCs are responsible for technical support and finding solutions for technical problems that have an impact on the environment. The second group consists of members of the Enterprise Europe Network (EEN), who are responsible for connection with SMEs and raise awareness of the open-eco-innovation network. One of the EEN partners is ruling the coordination of the project and has the overall technical, administrative and financial responsibility for the organisation, planning and control of the project. It also ensures a reliable and rapid flow of information and project documentation within the project consortium. The general process (Figure 5) is such that the KET TCs discuss and precisely assess technical problems by the SMEs with environmental relevance. The proposals for technical solutions are based on clean technologies are defined by the KET TCs. These proposals are then sent back to the SMEs, which can assess whether the proposed solutions are or are not helpful for the mentioned problem.

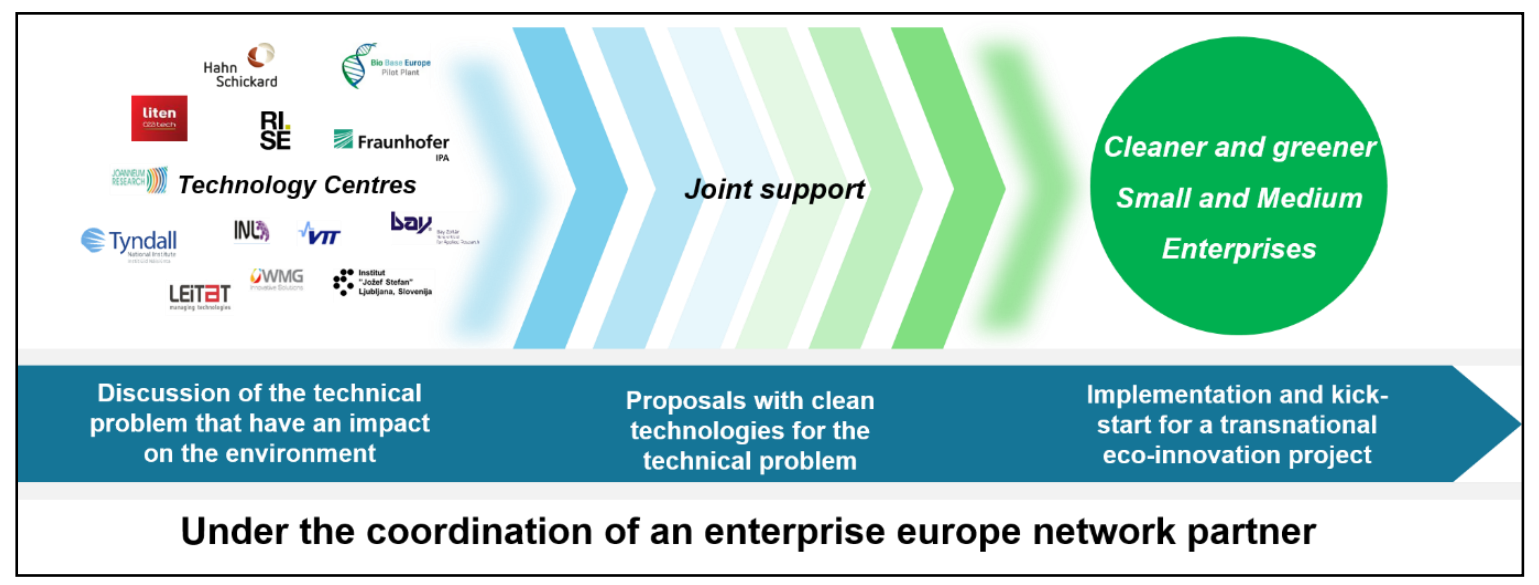

Figure 5. Overview of the open-eco-innovation process.

\subsubsection{Finding of SMEs for an Open-Eco-Innovations Project}

Systematic finding and identification of SMEs, which need such open-eco-innovations, is a challenging but important step. A survey of SMEs in Germany, Austria and Switzerland showed 
that $32.5 \%$ of respondents are in some way committed to open innovation [27]. In addition, a study showed that only SMEs with strong sensing, seizing and reconfiguration capabilities are more inclined to develop open innovation approaches [28]. Preliminary reports from a survey ran by the EU project KET4SME show that SMEs are not aware of KET TCs and the benefit that a collaboration can bring to their efficiency and operations [16]. Therefore, it is important to make SMEs aware that there are existing open-eco-innovation processes that are focusing on sustainable products. In the following, the communication and dissemination plan is explained:

- Highlight the benefits of the KET4SME platform to the SMEs and discuss how this type of collaboration can be realised and be proven to be mutually beneficial.

- $\quad$ Encourage and facilitate KET TCs to join the KET4SME network.

- Inform intermediaries about the available assistance to their clients.

- Apprise policy makers and public executives about the impact and achievements of the project.

To be effective, it is imperative that KET4CP reaches the right stakeholders with the right messages via the right communication channels at the right time [29]. The strategy of the dissemination and communications in the project followed five core directions, as depicted in Figure 6:

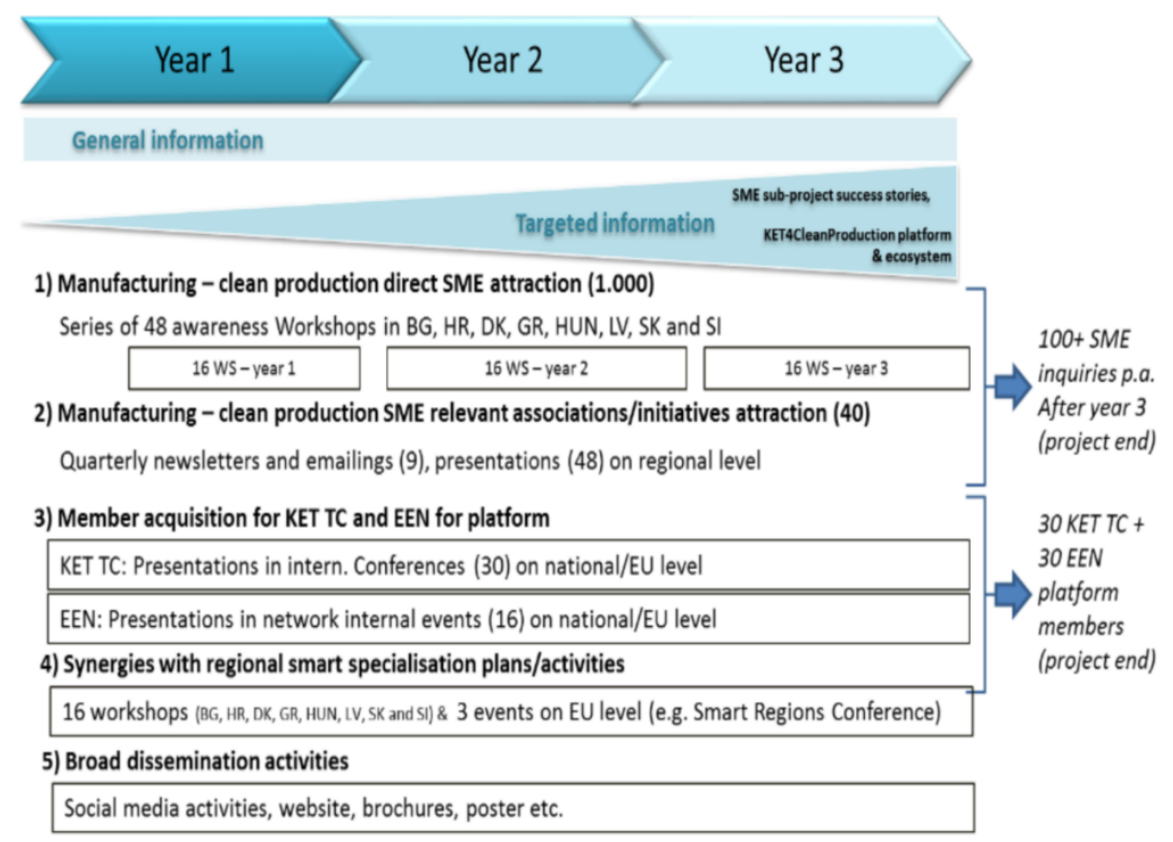

Figure 6. KET4CP dissemination and communication plan.

1. Attract interest of SMEs: reaching out directly to at least 1000 SMEs by conducting awareness workshops in countries with relatively little experience and available KET infrastructures. A total of 48 workshops throughout the duration of the project in the eight countries that have limited development in exploiting KETs, namely Bulgaria, Croatia, Denmark, Greece, Hungary, Latvia, Slovakia and Slovenia. Approximately 16 workshops are planned per year (two per country).

2. Contact SME relevant associations and initiatives with the aim to reach to 40 such associations. The main tools for this are the distribution of a newsletter every 3 months, with a total of nine issues, and presentations to 48 events at regional level. The presentations should be fairly distributed among the 3 years of project implementation.

3. Acquisition of new members for the KET4CP platform. The focus of this activity is to present and guide discussions about the project in targeted international conferences and/or specifically tailored meetings/events where representatives of KET centres attend or contribute. In addition, to attract the interest of EEN members, project partners should deliver presentations in EEN internal events at national, regional and European level. 
4. Exploitation synergies with activities at the regional level, namely regional smart specialisation plans. The plan involves 16 workshops in the selected eight countries and three additional events at EU level. Opportunities include the Smart Regions Conference.

5. Horizontal dissemination helps to spread the news and ideas of the project across the board. Social media are an important tool to disseminate news about the project, since they can be easily explored by the project consortium and the partners. In this context, a website is also valuable to build a frame of reference and a point of presence for the project. In addition, brochures/flyers and posters should be created for the use by the partners. Table 1 highlights the key elements of the dissemination and communications plan:

Table 1. Key elements of the dissemination and communications plan.

\begin{tabular}{|c|c|c|}
\hline Activities & Activities in Numbers & Audience to be Reached \\
\hline $\begin{array}{l}\text { Awareness events in } 28 \mathrm{EU} \\
\text { Countries }\end{array}$ & 30-40 events & $\begin{array}{c}2500 \text { manufacturing SMEs in EU28 } \\
\text { (thereof } 750 \text { in regions with difficult } \\
\text { KET access) }\end{array}$ \\
\hline Newsletters/electronic mailings & Nine quarterly mailings & $\begin{array}{l}40 \text { manufacturing related } \\
\text { clusters/initiatives informed in EU-28 }\end{array}$ \\
\hline $\begin{array}{l}\text { Participation of KET TC partners } \\
\text { in int. conferences/workshops on } \\
\text { applied KET research. } \\
\text { Contacting individual KET TCs } \\
\text { via phone/meetings }\end{array}$ & $\begin{array}{l}30 \text { presentations/poster stands } \\
30 \text { individual talks }\end{array}$ & 150 EU KET Technology Centres \\
\hline $\begin{array}{c}\text { Presentations in EEN internal } \\
\text { events (e.g., trainings, workshops, } \\
\text { sector groups meetings, annual } \\
\text { conference) }\end{array}$ & 16 presentations & $\begin{array}{l}150 \text { EEN partners certified as "special } \\
\text { KET contact point" } \\
\text { one MoU signed with EASME }\end{array}$ \\
\hline $\begin{array}{l}\text { Meetings with public authorities: } \\
\text { presentation of findings SME } \\
\text { mapping and success/impact of } \\
\text { cross border KET service support }\end{array}$ & 16 individual meetings & $\begin{array}{c}60 \text { representatives of public authorities } \\
\text { (Bulgaria, Croatia, Greece, Hungary, } \\
\text { Denmark, Latvia, Slovakia, Slovenia) }\end{array}$ \\
\hline $\begin{array}{l}\text { Final conference in Brussels } \\
\text { Participation in smart } \\
\text { specialisation events on EU level } \\
\text { (e.g., Smart Regions Conference) }\end{array}$ & $\begin{array}{l}\text { One final conference } \\
\text { Three presentations }\end{array}$ & $\begin{array}{l}200 \text { stakeholders from public sector } \\
\text { and KET Technology Centres }\end{array}$ \\
\hline Social media posts & $\begin{array}{c}\text { Frequent project updates and } \\
\text { news development }\end{array}$ & $\begin{array}{l}\text { Key stakeholders as well as } \\
\text { business/social communities and other } \\
\text { interested parties }\end{array}$ \\
\hline $\begin{array}{l}\text { Publication of success stories on } \\
\text { the website-freely downloadable }\end{array}$ & $\begin{array}{l}10 \text { success stories in written } \\
\text { form and three videos }\end{array}$ & $\begin{array}{l}\text { SMEs, KET Technology Centres, policy } \\
\text { makers and any interested party }\end{array}$ \\
\hline
\end{tabular}

\subsubsection{Definition of an Eco-Technical Request}

In an open-innovation process, users are usually asked to suggest ideas or to solve predefined problems in collaboration with others [30]. Ideally, a predefined problem as a technical request (TR) of a SME should not only be unambiguous, complete, and understandable to non-technical stakeholders, but also traceable to business processes and verifiable by means of automated analysis. One way to ensure for an ideal definition of technical problems is to use convenient templates [31]. Furthermore, it is important to help SMEs to address their technical problem via TR form. In the project KET4CP more than 130 TRs were submitted by SMEs. The figure shows that SMEs are willing to participate in an open-eco-innovation process and the awareness measures from the EEN partners were successful.

As the first document, that brings SME in contact with KET TCs and which helps SME to address a technical problem, TR needs to be understandable and easy to complete without professional help. 
The whole process of matching SMEs and KET TCs needs to be sustainable so creating a form that is easy-to-use and which can be later implemented into online form was the main concern. As the SMEs tend to not have time, willingness or motivation to file long and extensive forms, the idea is to develop a short and concise document for them to briefly highlight their main environmental technical problem. It is important for KET TCs as well, to get the idea about SME and their technical problems and to get the vision of potential cooperation. It is expected that SMEs can complete the form by themselves. It was based on existing documents e.g., EEN's Technology Request and modified to adjust KET4CP project's needs. The TR form can be divided into two sections:

I. Company details.

II. Technology request (with environmental impacts).

The first section (company details) includes information about the SME as name of the company, type, branch and other contact information (Appendix A: first page template TR). The second section (technology request details) is the main section of the document. This part includes more technological information as description of the problem, company and stage of development (Appendix B: second page template TR). To ensure the good quality of a TR form, it is recommended:

- To keep it clear and concise: avoiding long sentences or lists. Targeting the generalists/ non-specialists and avoid jargon. Explaining acronyms and abbreviations.

- To check spelling and grammar: running a spell check before submitting a profile-MS-Office can be used for that purpose. Reading the TR form once again before submitting it. Avoiding unnecessary use of capital letters.

- To make sure that the TR form is consistent.

- To avoid repetitions (i.e., copy-paste).

- To avoid marketing speech (the profile should not sound like an advertisement).

In summary, a TR form is a set of questions developed to address the SMEs production problem. The form is also the first document that presents SME to a potential KET TC. That is the base on which SMEs and KET TCs develop their potential partnership. It is important that the document includes all important issues and yet nothing confidential. In this first document environmental questions or objectives were deliberately not set because that would be difficult for SMEs to find and define impacts for the environment. This part will define the solution process with the KET TCs.

The intake of a TR takes place in such a way that the SME submits the TR, for which it could have received support from its EEN partner or already a KET TC. The project coordinator, which is an EEN partner, receives the SME TR, in Phase 1 via email and with the installation of the KET4CP platform all TRs were collected centrally. The SME TR will be uploaded to the internal Data Management Storage "owncloud" used by the project coordinator to store documents. Owncloud is used as a repository for SME TRs.

\subsubsection{Implementation and Solution-Process}

A weekly meeting with the KET TCs must be held and be led by an EEN. In this meeting the TRs are discussed which were sent to the KET TCs by the EEN partner a few days before. The KET TCs now have the opportunity to write an Expression of Interest (EoI). This EoI contains the following sections (Appendix C: Template for the Expression of Interest):

- $\quad$ KET TC organisation name.

- KET TC contact data including geographical location.

- Primary communication language.

- Proposed technical understanding (envisaged solution to the technical request of the SME).

- Proposed budget of the service.

- Proposed team experience. 
In addition to this information, the later preparation of the implementation contract could start with this information. A key point for the process is that this must be a simple process for both SMEs and the KET TCs. Using EoI templates at the application stage with this level of detail increases the administrative burden for the KET TC before addressing the SME. Furthermore, SMEs are usually not KET experts and need extensive guidance on which role the EEN partner should play. If more than one EoI has been prepared, it must be checked whether the EoIs are complementary in order to ensure that the KET TCs cooperate in preparing a joint project with the SME. If the EoIs (or complementary EOIs) meet the requested criteria, the coordinator sends the EOIs to the SME for selection. In this way, the SME is given some choice. The SME is responsible for selecting its preferred KET TCs from the short list of KET TCs, which contains a number of recommendations. In the case of multiple matches, the choice of KET TCs is made by the SME. Once the SME has decided on the most appropriate EoI/KET TC (or several KET TCs), the moderator(s) of this KET TCs will continue to contact the SME of a particular TR. There will only be one main contact person for the SME, who will serve the purpose of the KET TC. The selected KET TC develops the concept together with the SME and assists in applying for a Micro Grant Proposal (MGP). As the project is EU funded it is rather called an MGP instead of an implementation plan. Once the potential match between the SME and the KET TC is established, the KET TC will first contact the producing SME by e-mail or telephone to further inquire about its clean production challenge or the development of environmentally friendly products. If there is a high potential for clean development or clean production, the KET TC will visit the SME on site and together they will work out a concept for implementing a clean production or a clean product project (the second KET TC could complement the concept). The projects were implemented within 6 months.

In an open-innovation process, the intellectual property is an important point for the SME [32]. Therefore, there should be a clear and simple consensus on a non-disclosure agreement (NDA). In the project KET4CP each KET TC or each SME can use and provide its own NDA. For this reason, no specific rule or NDA template was established in the project. It was found that the SMEs are open and cooperative about the KET TCs in defining the NDA. In all so-called micro grant projects, the NDA process has never been a criterion for exclusion.

In summary, the process of implementation can be categorised into three main parts (Figure 7). These are activation, planning and implementation. In the activation part SMEs are made aware that eco-innovation is important for SMEs in terms of customer satisfaction, competitiveness and legislation and that open innovation is considerably suitable for this. Furthermore, the activation will introduce the organisational and technical support through KET TCs and EENs as well as the success stories of already implemented projects. After the SME, through the support of the EENs and KET TCs, has defined a technical need in the form of a technical request with environmental benefits, the planning phase begins. In this second phase, the technical requests with ideas for environmentally friendly effects are examined by the KET TCs and evaluated concerning the feasibility. Additionally, proposals for possible environmental improvements are made by KET TCs. During this process, all KET TCs exchange ideas, which leads to a high level of innovation. To ensure that the third and final step of implementation works smoothly, the legal and organisational framework for implementation is also clarified in this phase. These activities are supported by a web platform. 


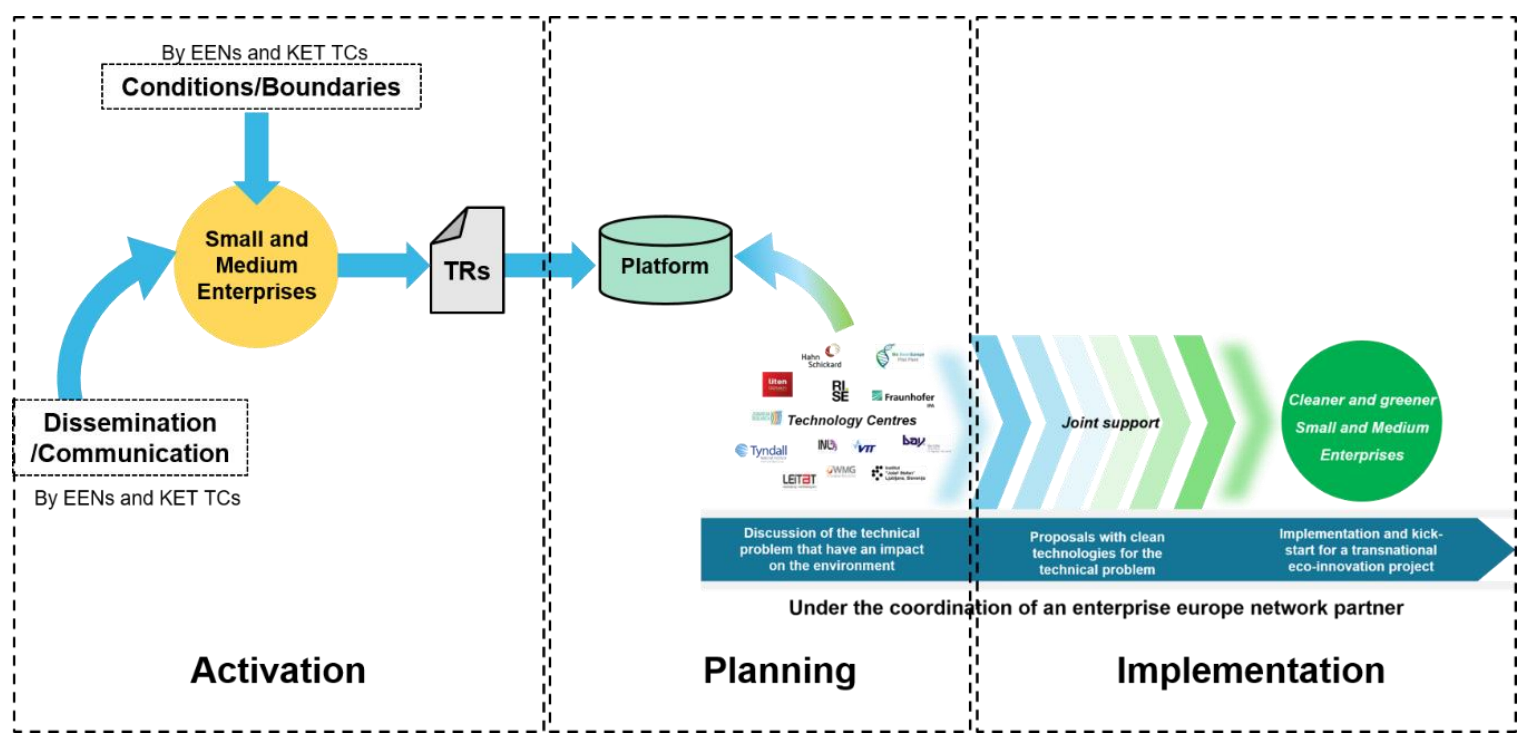

Figure 7. Whole open-eco-innovation process with KET TCs, SMEs, and EENs.

This process was developed by a workshop with experts and the stakeholders of this process and was based on the analysed research question. The next chapter will apply the developed process and show the results. Therefore, this process will be tested, inter alia, with the presentation of how many projects are completed and with one project described in detail.

\subsection{Example of Application for an Open-Eco-Innovation Process}

This section shows an example of an eco-open-innovation project carried out with an SME and a KET TC. In this case the SME was found by an EEN partner during the dissemination of the KET4CP project and was accompanied until the TR preparation. Therefore, the importance of the processes to be followed until the TR preparation is clear. Knot Ltd. (SME) (Auckland, New Zealand) wished to develop an innovative water turbine which can be fitted within the water piping network to harness electricity owing to loss of potential energy and deliberate velocity reduction in off-peak times. Such turbines need to be developed and manufactured with the highest possible functionality. However, the SME lacked some of the competencies required to design and manufacture an adequately optimised turbine. Specialised in water monitoring and sensor systems, the SME had no experience with simulations. Through the direct contact of an EEN Partner the SME received the information about KET4CP. Accompanied by the EEN partner the SME submitted a TR with its idea and the problem. Different sizes and models of turbines were planned by the SME in order to implement the turbine for various applications involving city water pipes or rainwater harvesting drains to name a few. A simulation model was, therefore, set up through this project by Hahn-Schickard (KET TC) to analyse the functionality of such a turbine. This developed simulation model provides a basis for future implementation involving different combinations of turbine designs and flow parameters.

The geometry model provided by the SME was checked and imported in ANSYS which was used for the analysis of the system. Only the rotor of the turbine was considered for the further analysis. Pipe water volumes before, through and after the rotor were conceptualised and added to the model. This conception can be seen in Figure 8. The rotor is imported and retained as a solid part. 


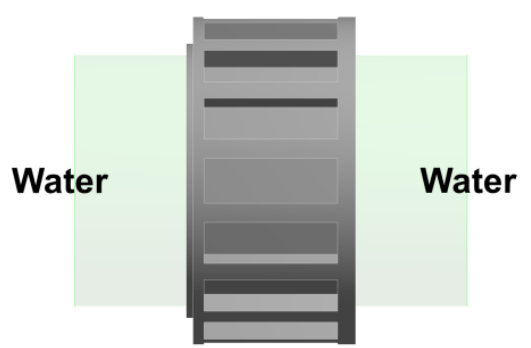

Figure 8. Conception of the simulation model involving the rotor geometry and volume of water.

Execution of the Project

A process flow or roadmap was defined and agreed upon by the stakeholders involving phases ranging from definition of the problem, governing process parameters, and simulation strategy to output evaluation. Figure 9 depicts these mentioned phases. At the end of every phase, the interim results were discussed and laid open for feedback amongst the project partners.

\section{Roadmap}

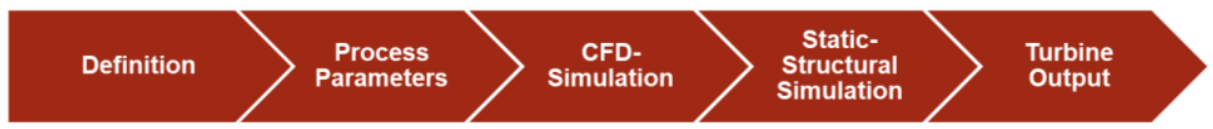

Figure 9. Process flow definition for the execution of the project.

The stages of the simulation are depicted in Figure 10. A mesh is generated and shown in Figure 10a which is deemed suitable for a fluid flow analysis. The mesh quality parameter limits are set according to standards for computational fluid dynamics.
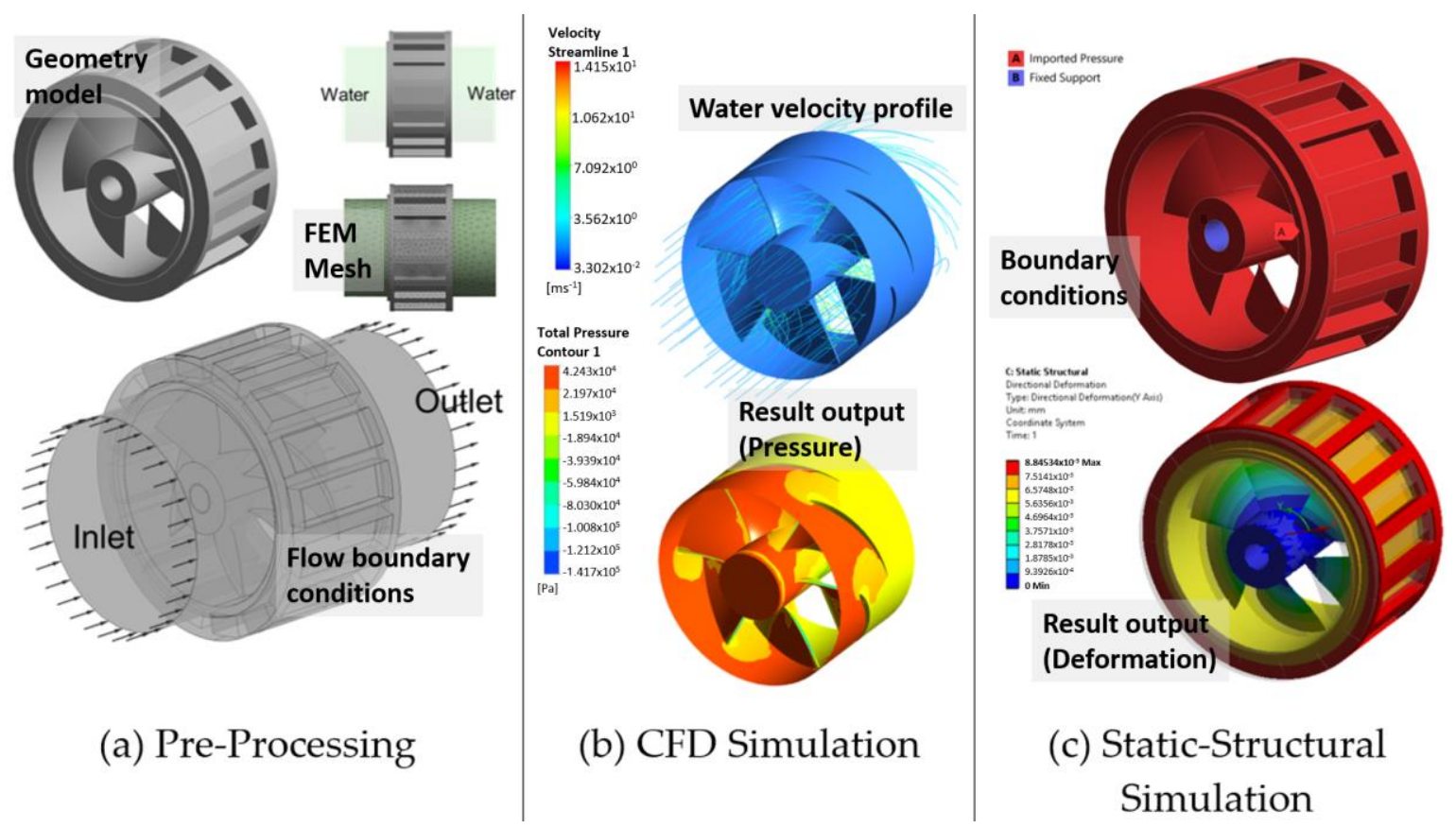

Figure 10. Overview of the stages involved for the development of the simulation model. (a) Pre-processing; (b) CFD simulation; (c) static-structural simulation.

Boundary conditions are defined in a quasi-static setting, where the fluid is considered with flowing conditions and the rotor is assumed static to obtain pressure acting on its surface as a reaction 
for the further analysis. A flow condition of $2 \mathrm{~m} / \mathrm{s}$ at inlet and same value at outlet is applied. The conversion of energy occurs owing to loss in potential head. Figure 10a shows how these boundary conditions are applied and depicts the marked surfaces for the defined inlet and outlet domains.

The output of the analysis is evaluated firstly on the basis of the velocity profile. The tracers in Figure $10 \mathrm{~b}$ show a maximum water particle velocity of $14.15 \mathrm{~m} / \mathrm{s}$. A video of the simulated output is provided as supplementary data to this paper. Figure $10 \mathrm{~b}$ also shows the pressure distribution built-up on the surface of the rotor. This output from the fluidic simulation plays the role of the prime input parameter for the mechanical analysis. The output rightfully exhibits a positive pressure distribution on the inlet side of the rotor while negative values are yielded on the output side of the rotor.

Relevant boundary conditions (assuming static case) are applied in the mechanical analysis and are depicted in Figure 10c. The interface of the rotor with the shaft is assumed as fixed support to obtain the torque generated by the water flow owing to loss in potential head. The directional deformation of the rotor is plotted also in Figure 10c in the cylindrical direction. This analysis can be used to get a qualitative torque output of the water turbine.

This analysis know-how was transferred by the KET TC to the SME. The SME, therefore, was provided with the opportunity to implement this analysis method by changing the flow parameters to be able to plot dependent outputs. The simulation model can be further used with modified geometry variants to qualitatively gauge the relative change in the output of the turbine. Possible variations here could be scaling up or down of the rotor model for different outputs, different pipe diameters, varying water velocity levels, or angular positions with respect to gravity. A change in any of the parameters will give a change in the output and, thus, the new design can be compared to the reference model.

According to the classification matrix system from Harbour et al. (2006) this product innovation can be allocated to type II. Innovations of type II mean that is based on a radical change in form but an only elementary change in internal components [2]. The water turbine is designed for city water pipes which is a complicated form. Thus, the SME used additive technologies for building quicker prototypes. Components for harnessing energy with the turbine are standard components but have been incrementally optimised, i.e., by surface treatment. Although it is type II, it has the potential for the same effects as type IV, because in the city water pipes these turbines are not used yet and therefore old systems (pressure reducing) in the city water pipes can be eliminated and new markets can be created.

\section{Results}

By applying the methodology, as explained in the second chapter of this paper, many TRs from SMEs could be collected and processed by KET TCs with innovative solutions. SMEs from more than $21 \mathrm{EU}$ countries participated in this open-eco-innovation process. Furthermore, more than 30 KET TCs registered for the platform. In the framework of the KET4CP project, 40 eco-innovation projects should be completed. These were achieved and the demand from SMEs for eco-innovations is increasing. About 130 TRs from SMEs were received. KET TCs proposed technical solutions for approximately $90 \%$. Furthermore, it could be observed that the problems and aversions to open innovations in general, which were mentioned at the beginning of the paper, for example the trust in the handling of the technical problem definition, are reduced by third neutral partners, as in this case the EENs were. It was also be confirmed that eco-innovation needs interdisciplinary competences. The past showed that many SMEs have proposed solutions in TR, but there was a lack of expertise in a particular area where SMEs were not engaged. The KET TCs were very suitable in filling these lacking competencies in a complementary way. Moreover, it has been shown that the time from the beginning to the end of such a project takes about 7 months. While the process of finding an idea is made in a relatively short time, the technical implementation requires comparatively the most time. The SMEs rated the projects as successful, i.e., the desired ecological improvements were achieved. A verification of this evaluation was not carried out.

The research finding are as follows: 
- Clean, sustainable or green production is (very) important for $68 \%$ of the SMEs surveyed;

- $\quad$ KET TCs are able to support SMEs efficiently regarding clean production;

- EENs play an important role in the implementation and management of open-ecoinnovation processes;

- A pan-European triangular open innovation process has enabled many innovation projects that were completed within 7 months;

- Dissemination and communication activities are important to overcome distrust of general open-innovation projects;

- The communication exclusively via digital media led to difficulties in understanding the technical problem/solution;

- A personal meeting is costly but very helpful for SMEs and KET TCs in regard to understanding the problem of SME and solution of the KET TC;

- Not all TRs could be checked in detail, as many new ones were added.

With these findings and the examined definition of open innovation and eco-innovation, the open-eco-innovations can be defined as a series of action or steps taken with different external technological partners and a one-stop shop solution in order to implement ecological engineering (note that ecological engineering combines the disciplines of ecology and engineering in order to solve environmental problems (Kangas 2003) [33]) which is new, more efficient than pre-existing alternatives as well as technically feasible and economically viable.

\section{Conclusions}

This paper showed that clean, sustainable and green production plays an important role for companies. Furthermore, this paper presented a method of implementing a successful open innovation process within Europe for SMEs, which are aiming to become cleaner and greener. The success is characterised by the fact that many technical requests were received in a short time from different countries within Europe and many solutions were generated very fast. The success is based, in particular, on the familiar contacts with the EEN partners, systematic dissemination and communication plan, user-friendly templates and platform, the regular consultation of KET TCs and the regular dealing of the KET TCs with the technical problems of SMEs. Due to the success, the method will be continued without the support of EU funding. One point of criticism may be that the SMEs participated in the open-eco-innovation process in such large numbers just because of the micro grant from the EU. Further research approaches would be the examination of the open-eco-innovation process without the micro grant and with other participants.

As there is no common definition for the term open-eco-innovation and so it is difficult to envisage anything specific under this term, the used methodology allows increasing the semantic value of the word, which means, the meaning of the word becomes more specific. The specification of a term and pointing out examples allows to convey the meaning of a term [34], which was done in this paper.

A use case and its innovative classification was shown. Thereby, the SME from Hungary had an idea for energy harvesting with an innovative application, but the required technologies for an efficient development and manufacturing were missing. Consequently, the KET TC from Germany provided support. The KET TC developed a FEM simulation for this purpose, so that the SME can derive a qualitative statement of the efficiency. Furthermore, this simulation can be used for different models. Thus, a comparability between different models is possible.

The open-eco-innovation led to new and green products but the communication barriers decelerated the implementation and solution process. SMEs pay a percentage of the costs for the service. Yet, it is to assume that the SMEs would not take advantage of the Open-Eco-Innovation service if they had to cover the full costs of the KET TCs themselves. Then, the business model must be considered above all. A further research study could be to systematically classify all 40 innovative projects carried out through the open-eco-innovation process and to identify patterns. 
Author Contributions: Conceptualization, F.C., R.K., T.M., C.T. and A.Z.; methodology, F.C., T.M., C.T.; validation, K.-P.F., A.Z. and T.G.; Formal Analysis, F.C., K.-P.F., and A.Z.; Investigation, F.C., T.M., and C.T.; Resources, F.C.; Data Curation, F.C.; Writing-Original Draft Preparation, F.C., and R.K.; Writing-Review \& Editing, T.M., C.T., A.Z., and K.-P.F.; Visualization, F.C.; Supervision, A.Z.; Project Administration, F.C., T.M., C.T., and T.G.; Funding Acquisition, K.-P.F., and T.G. All authors have read and agreed to the published version of the manuscript.

Funding: This research was funded by the European Union's Horizon 2020 research and innovation programme under grant agreement No 777441.

Conflicts of Interest: The authors declare no conflict of interest.

\section{Appendix A}

\section{骂KET4}

\section{Technology Request Form}

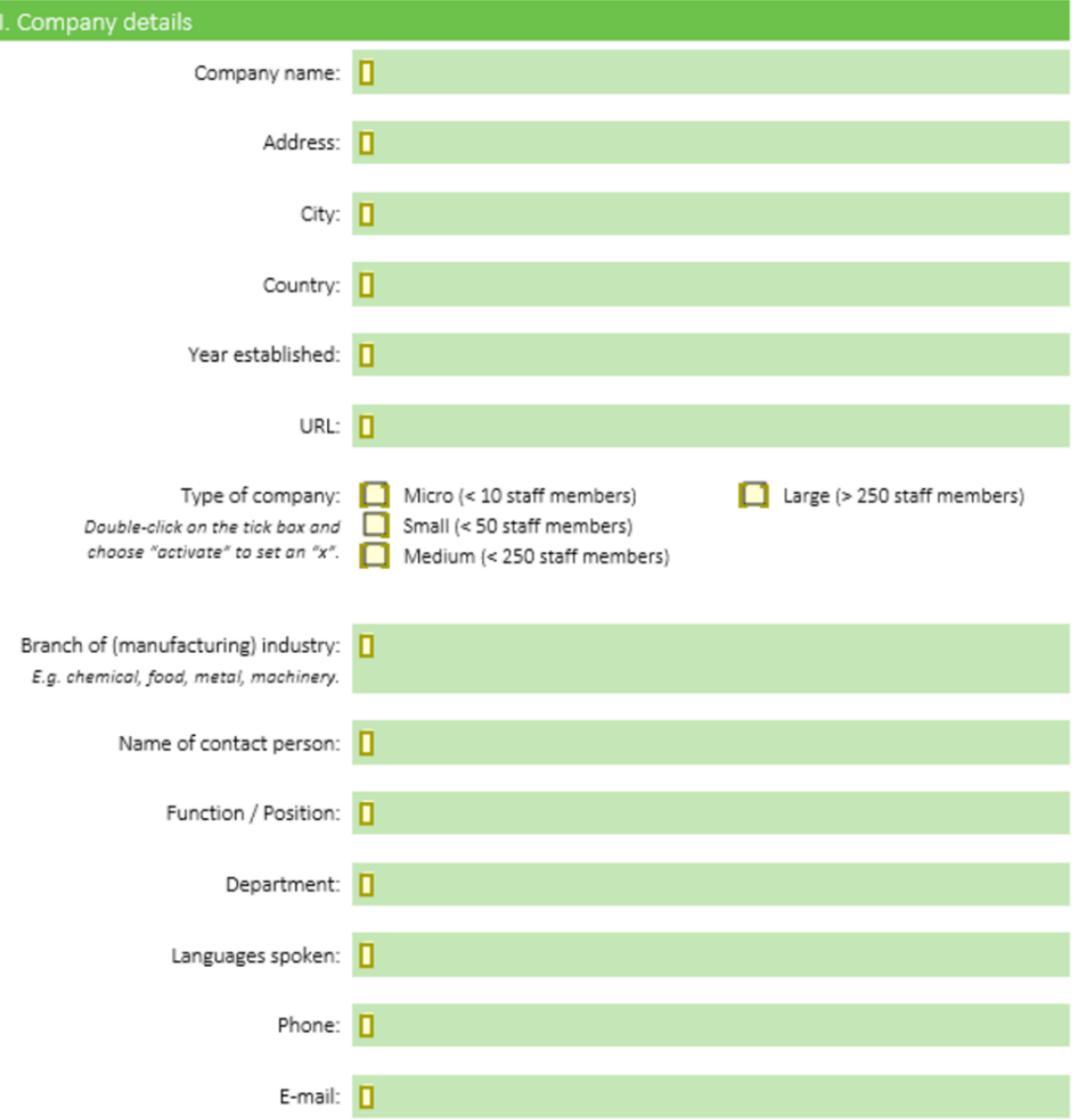

Figure A1. First page template TR. 


\section{Appendix B}

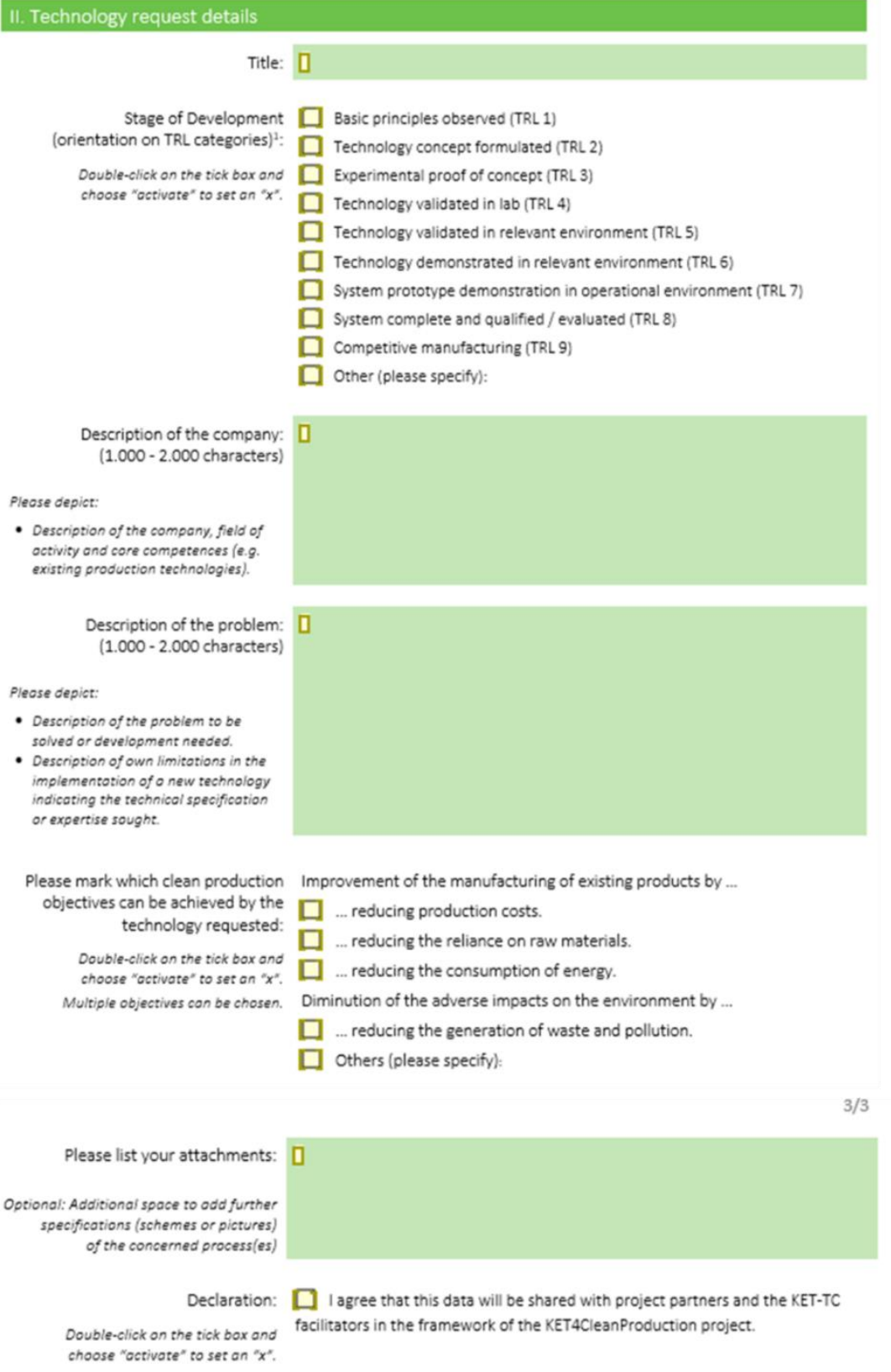

Figure A2. Second page template TR. 


\section{Appendix C}

\section{Expression of Interest}

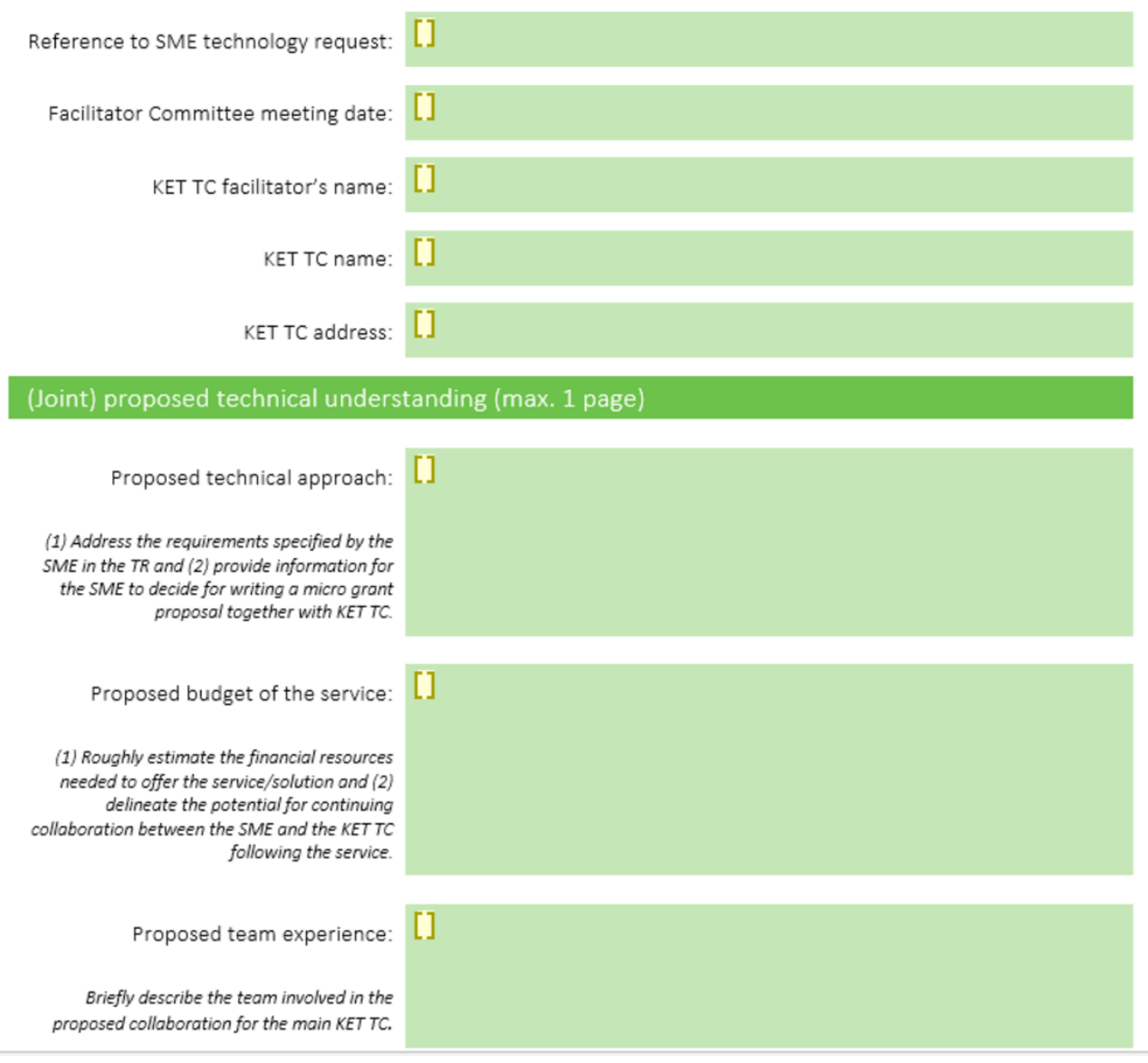

Figure A3. Template for the expression of interest.

\section{References}

1. Phills, J.A., Jr.; Deiglmeier, K.; Miller, D.T. Rediscovering social innovation. Stanf. Soc. Innov. Rev. 2008, 6, 34-43.

2. Tabas, J.; Beranová, M.; Polák, J. Classification of innovations: Approaches and consequences. Acta Univ. Agric. Silvic. Mendel. Brun. 2011, 59, 399-406. [CrossRef]

3. Harbour, J.L.; Blackman, H.S. Innovation: The other " $\mathrm{i}$ " word associated with performance: Innovation. Perform. Improv. 2006, 45, 24-29. [CrossRef]

4. Adams, R. Perceptions of Innovations: Exploring and Developing Innovation Classification. Ph.D. Thesis, Cranfield University, Cranfield, UK, September 2003; p. 347. Available online: https://dspace.lib.cranfield.ac. uk/bitstream/handle/1826/124/adams.pdf?sequence=2\&isAllowed=y (accessed on 11 October 2020).

5. Von Hippel, E. Democratizing Innovation; MIT Press: Cambridge, MA, USA, 2005.

6. Joe, T. Open Innovation Research, Management and Practice; World Scientific: Sussex, UK, 2013.

7. Chesbrough, H.W. Open Innovation: The New Imperative for Creating and Profiting from Technology; Harvard Business Press: Brighton, MA, USA, 2006.

8. Lehr, U.; Lobbe, K. Umweltinnovationen-Anreize und hemmnisse. Ökologisches Wirtsch. Fachz. 1999, 14. [CrossRef]

9. Rennings, K. Redefining innovation-Eco-innovation research and the contribution from ecological economics. Ecol. Econ. 2000, 32, 319-332. [CrossRef] 
10. Eisenhardt, K.M.; Graebner, M.E. Theory building from cases: Opportunities and challenges. Acad. Manag. J. 2007, 50, 25-32. [CrossRef]

11. Troulos, C. D1.1-Report-on-SME-Needs-Analysis-Outcomes-and-Framework-Conditions.pdf. ket4sme.eu, 2019. Available online: https://www.ket4sme.eu/wp-content/uploads/2018/01/D1.1-Report-on-SME-needsanalysis-outcomes-and-framework-conditions.pdf (accessed on 19 August 2020).

12. Ivankova, N.V.; Creswell, J.W.; Stick, S.L. Using mixed-methods sequential explanatory design: From theory to practice. Field Methods 2006, 18, 3-20. [CrossRef]

13. Doszhanov, A.; Ahmad, Z.A. Customers' intention to use green products: The impact of green brand dimensions and green perceived value. SHS Web Conf. 2015, 18, 1008. [CrossRef]

14. Shao, J.; Ünal, E. What do consumers value more in green purchasing? Assessing the sustainability practices from demand side of business. J. Clean. Prod. 2019, 209, 1473-1483. [CrossRef]

15. Noci, G.; Verganti, R. Managing 'green' product innovation in small firms. RED Manag. 1999, $29,3-15$. [CrossRef]

16. Report on SME Needs Analysis Outcomes and Framework Conditions. ec.europa.eu. Available online: https://ec.europa.eu/research/participants/documents/downloadPublic?documentIds= 080166e5c09cb260\&appId=PPGMS (accessed on 22 April 2020).

17. Cheng, K.; Srai, J.S. Special issue on sustainable manufacturing and the key enabling technologies. Proc. Inst. Mech. Eng. Part B J. Eng. Manuf. 2012, 226, 1603. [CrossRef]

18. Teirlinck, P.; Spithoven, A. Research collaboration and R\&D outsourcing: Different R\&D personnel requirements in SMEs. Technovation 2013, 33, 142-153. [CrossRef]

19. Esty, D.C.; Winston, A. Green to Gold: How Smart Companies Use Environmental Strategy to Innovate, Create Value, and Build Competitive Advantage; John Wiley \& Sons: Hoboken, NJ, USA, 2009.

20. KET4CleanProduction. KET4CleanProduction / Connecting SMEs and KET Technology Centres across Europe. Available online: https://www.ket4sme.eu/ (accessed on 14 April 2020).

21. Perkmann, M.; Walsh, K. University-industry relationships and open innovation: Towards a research agenda. Int. J. Manag. Rev. 2007, 9, 259-280. [CrossRef]

22. Chesbrough, H.; Vanhaverbeke, W.; West, J. Open Innovation: Researching a New Paradigm; OUP Oxford: Berkeley, CA, USA, 2006.

23. Stefan, I.; Bengtsson, L. Unravelling appropriability mechanisms and openness depth effects on firm performance across stages in the innovation process. Technol. Forecast. Soc. Chang. 2017, 120, 252-260. [CrossRef]

24. Gianiodis, P.T.; Ellis, S.C.; Secchi, E. Advancing a typology of open innovation. Int. J. Innov. Manag. 2010, 14, 531-572. [CrossRef]

25. User_Administrator. Open Innovation Ideal for Eco-Innovation. Eco-innovation Action Plan-European Commission. 2015. Available online: https://ec.europa.eu/environment/ecoap/about-eco-innovation/policiesmatters/eu/20130708_open-innovation-ideal-for-eco-innovation_en (accessed on 14 April 2020).

26. Reichwald, R.; Piller, F.T. Interaktive Wertschöpfung: Open Innovation, Individualisierung und neue Formen der Arbeitsteilung; Gabler: Wiesbaden, Germany, 2009.

27. Lichtenthaler, U. Open innovation in practice: An analysis of strategic approaches to technology transactions. IEEE Trans. Eng. Manag. 2008, 55, 148-157. [CrossRef]

28. Grimaldi, M.; Quinto, I.; Rippa, P. Enabling open innovation in small and medium enterprises: A dynamic capabilities approach: Enabling open innovation in SMEs. Knowl. Process. Manag. 2013, 20, 199-210. [CrossRef]

29. Spreading the Word: Practical Guidelines for Research Dissemination Strategies. Phase II Literature Review. 2019. Available online: https://repository.lboro.ac.uk/articles/online_resource/Spreading_the_ word_practical_guidelines_for_research_dissemination_strategies_Phase_II_literature_review/9582668 (accessed on 13 July 2020).

30. Hrastinski, S.; Kviselius, N.Z.; Ozan, H.; Edenius, M. A review of technologies for open innovation: Characteristics and future trends. In Proceedings of the 2010 43rd Hawaii International Conference on System Sciences 2010, Honolulu, HI, USA, 5-8 January 2010; pp. 1-10. [CrossRef]

31. Del-Río-Ortega, A.; De Reyna, M.R.A.; Toro, M.; Ruiz-Cortés, A. Defining process performance indicators by using templates and patterns. In Business Process Management; Springer: Sevilla, Spain, 2012; pp. 223-228. [CrossRef] 
32. Toma, A.; Secundo, G.; Passiante, G. Open innovation and intellectual property strategies: Empirical evidence from a bio-pharmaceutical case study. Bus. Process. Manag. J. 2018, 24, 501-516. [CrossRef]

33. Kangas, P. Ecological Engineering: Principles and Practice; CRC Press: Boca Raton, FL, USA, 2003.

34. Flowerdew, J. Definitions in science lectures. Appl. Linguist. 1992, 13, 202-221. [CrossRef] 